\title{
Distributions and sources of petroleum, aliphatic hydrocarbons and polycyclic aromatic hydrocarbons (PAHs) in surface sediments from Bohai Bay and its adjacent river, China
}

\author{
Min Wang ${ }^{\mathrm{a}}$, Chuanyuan Wang ${ }^{\mathrm{b}, *}$, Xiaoke Hu ${ }^{\mathrm{b}}$, Haijiang Zhang ${ }^{\mathrm{e}}$, Shijie He ${ }^{\mathrm{b}, \mathrm{c}}$, Shuangyan Lv ${ }^{\mathrm{d}}$ \\ ${ }^{a}$ Management Science and Engineering Institute, Shandong Institute of Business and Technology, Yantai 264025, China \\ ${ }^{\mathrm{b}}$ Key Laboratory of Coastal Zone Environmental Processes, Yantai Institute of Coastal Zone Research, Chinese Academy of Sciences, Yantai 264003, China \\ ${ }^{\mathrm{c}}$ First Institute of Oceanography, State Oceanic Administration, Qingdao 266061, China \\ ${ }^{\mathrm{d}}$ College of Geography and Planning, Ludong University, Yantai 264025, China \\ e Yantai Oil Spill Response Technical Center of China MSA, Yantai 264003, China
}

\section{A R T I C L E I N F O}

\section{Article history:}

Available online 8 December 2014

\section{Keywords:}

Costal zone of Bohai Bay

Petroleum hydrocarbon

Aliphatic compounds

PAHs

Sources

Ecological risk assessments

\begin{abstract}
A B S T R A C T
Surface sediment samples from Bohai Bay and its adjacent river, China, were analyzed for aliphatic hydrocarbon, PAHs and biomarkers in order to determine the distribution, composition and source of organic matter in a coastal environment. Results suggested that the input of organic matter from anthropogenic activities has a more significant influence on its distribution than that from natural processes. Petroleum contamination, mainly from offshore oil exploration and discharge of pollutants from rivers, was the main source of $n$-alkanes. PAHs were mostly of pyrogenic origin; while some sites in Yellow River Estuary were derived mainly from the petrogenic sources. The toxic assessment suggested that the PAHs in surface sediments will not cause immediately adverse biological effects in sediments from Bohai Bay and its adjacent river, China.
\end{abstract}

(c) 2014 Elsevier Ltd. All rights reserved.
Estuaries and coastal zones are the main channels between the lands and the oceans, which can trap significant quantities of natural and anthropogenic organic matter (OM) under the interactions of a series of physical, chemical and biological processes (Thornton and McManus, 1994; Liu et al., 2012). Land-derived OM can be transported into the marine systems by river discharge and atmospheric deposition. Bohai Bay is a large, semi-enclosed shallow water basin located along the western region of Bohai Sea in the northeastern part of China. Over the last decade, rapid economic development and urbanization have significantly impacted on its environments. These changes, in turn, have the potential to alter the nature and content of OM of marine deposits in Bohai Bay.

Hydrocarbons are abundant components of organic material in coastal zones, and one of the major classes of organic compounds. Among the organic contaminants, aliphatic and polycyclic aromatic hydrocarbons (PAHs) have received much attention due to their ubiquitous distribution in marine sediments (e.g. Sultan and Sameer, 1997; Zanardi et al., 1999; Wang et al., 2006; Liu et al., 2009; Yang et al., 2009; Commendatore et al., 2012; Kanzari et al., 2014). There are several reports on the environmental

\footnotetext{
* Corresponding author. Tel.: +86 05352109152.

E-mail address: cywang@yic.ac.cn (C. Wang).
}

aspects of Bohai: seawater (Hu et al., 2005), sediment (Ma et al., 2001; Hu et al., 2009) and biota (Zhou et al., 2007). However, detailed information on petroleum and aliphatic hydrocarbon distribution in this region remains scarcely documented, especially covering both the marine and riverine regions. Here, the levels of aliphatic hydrocarbon (total and linear alkanes), PAHs and petroleum biomarker (terpanes and steranes) were measured in surface sediments of coastal Bohai Bay to determine the distribution, composition, source and the factors controlling their distribution and accumulation. A systematic survey on inputs of petroleum pollutant from main continental rivers flowing into Bohai Bay was also conducted.

Sediments used in this study were collected from 40 sites of coastal Bohai Bay in April 2012. The sampling stations were arranged along the major rivers (Luanhe River, Douhe River, Yongdingxinhe River, Ziyaxinhe River and Yellow River) of this area extending from the land to the sea and formed five transects (TA, TB, TC, TD and TE) (Fig. 1). The surface sediments from the marine region were collected using a Van Veen style stainless steel grab sampler, and the surface sediments from rivers were collected using a plastic spatula. The top $0-5 \mathrm{~cm}$ sediment was collected at each sampling site. After collection, the samples were homogenized and placed into sterile polyethylene bags, sealed and frozen at $-20^{\circ} \mathrm{C}$ in the dark until further analysis. 
Sediment samples were first dried at $60^{\circ} \mathrm{C}$ and separated with a $125-\mu \mathrm{m}$ sieve to remove large particles and debris. The dried sediment samples were then ground into powder with a mortar and pestle. For total lipid extraction, about $100 \mathrm{~g}$ dry sediment sample was Soxhlet-extracted with chloroform for a period of $72 \mathrm{~h}$. Elemental sulfur was removed from the extracts using activated copper. The extracts were fractionated by column chromatography on alumina over silica gel. Saturated hydrocarbons, aromatic hydrocarbons and non-hydrocarbons were obtained by successively eluting with $n$-hexane, toluene and chloroform/methanol (98:2), respectively. The aliphatic and aromatic fractions were concentrated again on a rotary evaporator, transferred to a vial, and then the volume was adjusted to $1 \mathrm{~mL}$ exactly using a stream of filtered $\mathrm{N}_{2}$ gas. An aliquot of $1 \mathrm{ml}$ of each extract was subjected to gas chromatography-mass spectrometry (GC-MS) analysis.

The aliphatic hydrocarbon were analyzed on Hewlett-Packard 6890 gas chromatograph interfaced with a Hewlett-Packard 5973 mass detector made by Agilent (USA). The samples were analyzed using a fused silica capillary column $(30 \mathrm{~m} \times 0.20 \mathrm{~mm} \times$ $0.25 \mu \mathrm{m}$ film thickness) with helium as carrier gas. The temperature was programmed from $80^{\circ} \mathrm{C}$ to $290{ }^{\circ} \mathrm{C}$ at $4{ }^{\circ} \mathrm{C} / \mathrm{min}$ and held at the final temperature for $30 \mathrm{~min}$. The injector temperature and transfer line temperature were $250^{\circ} \mathrm{C}$ and $180^{\circ} \mathrm{C}$, respectively. The mass spectrometer was operated at an electron energy of $70 \mathrm{eV}$ with an ion source temperature of $250^{\circ} \mathrm{C}$.

The concentration of $n$-alkanes was determined by using authentic standards of $n$-alkanes $\left(C_{16}, C_{20}, C_{24}, C_{28}\right.$, and $\left.C_{32}\right)$. Individual $n$-alkanes were identified based on the retention times and mass spectra of target compounds against the authentic standards. The terpanes and steranes were detected in their key mass chromatograms $(m / z 191,217)$ based on the relative retention times and by comparing their mass spectra with published data. The standard deviation of the calculations of the peak areas was better than $0.5 \%$. Individual PAHs were quantified based on the retention time and $m / z$ ratio of an authentic PAHs mixed standard (Sigma), and concentrations of each PAHs were calibrated based on the standard calibration curve. For quality assurance and quality control, the method blanks (solvent) and spiked matrixes (standards spiked into soil) were analyzed. None of the target compounds was detected. Seven surrogate standards (naphthalene-d8, acenaphthylene-d8, phenanthrene- $\mathrm{d} 10$, fluoranthene- $\mathrm{d} 10$, pyrene- $\mathrm{d} 10$, benzo(a)pyrene-d12 and benzo(g,h,i)perylened12) were added to all samples to monitor matrix effects. The average recoveries of surrogate standards varied from $81.6 \%$ to $92 \%$. In addition, the detection limit ranged from 0.15 to $0.7 \mathrm{ng} / \mathrm{g}$ dry weight (dw).

The sample granulometry was analyzed on fresh sediments using a Malvern Mastersizer 2000 laser diffractometer capable of analyzing particle sizes between 0.02 and $2000 \mu \mathrm{m}$. The percentages of the following three groups of grain sizes were determined: $<4 \mu \mathrm{m}$ (clay), 4-63 $\mu \mathrm{m}$ (silt), and >63 $\mu \mathrm{m}$ (sand).

A high abundance of aliphatic hydrocarbons in sediments is a potential source of pollution. The levels of $\sum n-C_{12-34}$ concentrations concentration of the studied sediments is $994.62 \pm$ $537.63 \mathrm{ng} \mathrm{g}^{-1}$ dry weight (Fig. 2), which were relatively lower or moderate compared to those of worldwide locations reported to be chronically contaminated by oil, such as $500-8120 \mathrm{ng} \mathrm{g}^{-1}$ in Jiaozhou Bay (Wang et al., 2006), 160-1880 ng g $^{-1}$ in Yangtze River Estuary (Bouloubassi et al., 2001), 100-14,560 $\mathrm{ng} \mathrm{g}^{-1}$ in highly contaminated sediments from Santos, Brazil (Medeiros and Caruso Bíego, 2004). Furthermore, the concentrations of $n$-alkane from North region are higher than those of South region (Fig. 2). Sediment granularity in intertidal zone showed the obvious difference of "fine in north" (dominated by clayey-silt) and "coarse in south" (dominated by sandy) (Fig. 3), which illustrated the different sedimentary dynamics in two areas, and it also explained the spatial difference of TOC and $n$-alkane concentration. The four tributaries, Suyun River, Yongding River, Duliujian River and Ziya River, produce a marked effect on discharge of flood for the Haihe River in summer. Based on the fact that the rivers flow through the main areas with high density of population in North China, hence, receiving plenty of sewage from cities was inevitable. Except Luanhe River and Yellow River, the total $n$-alkane concentrations of riverine sediment are much higher than that of offshore area, which suggested the fugitive petroleum contamination from sewage discharge from the Dohe River, Yongdingxinhe River and Ziyaxinhe River. In addition, the total $n$-alkane concentrations decrease seaward along all the studied transects (Fig. 2). This explanation is also consistent with the seaward decrease in autogenous organic carbon (Gao et al., 2012).

$n$-Alkanes in the sediment profiles showed two model (Fig. 4). The first model (Type A) range from $n-C_{12}$ to $n-C_{34}$, with $n-C_{29}$ or $n-C_{31}$ as maximum, and a significant odd carbon number

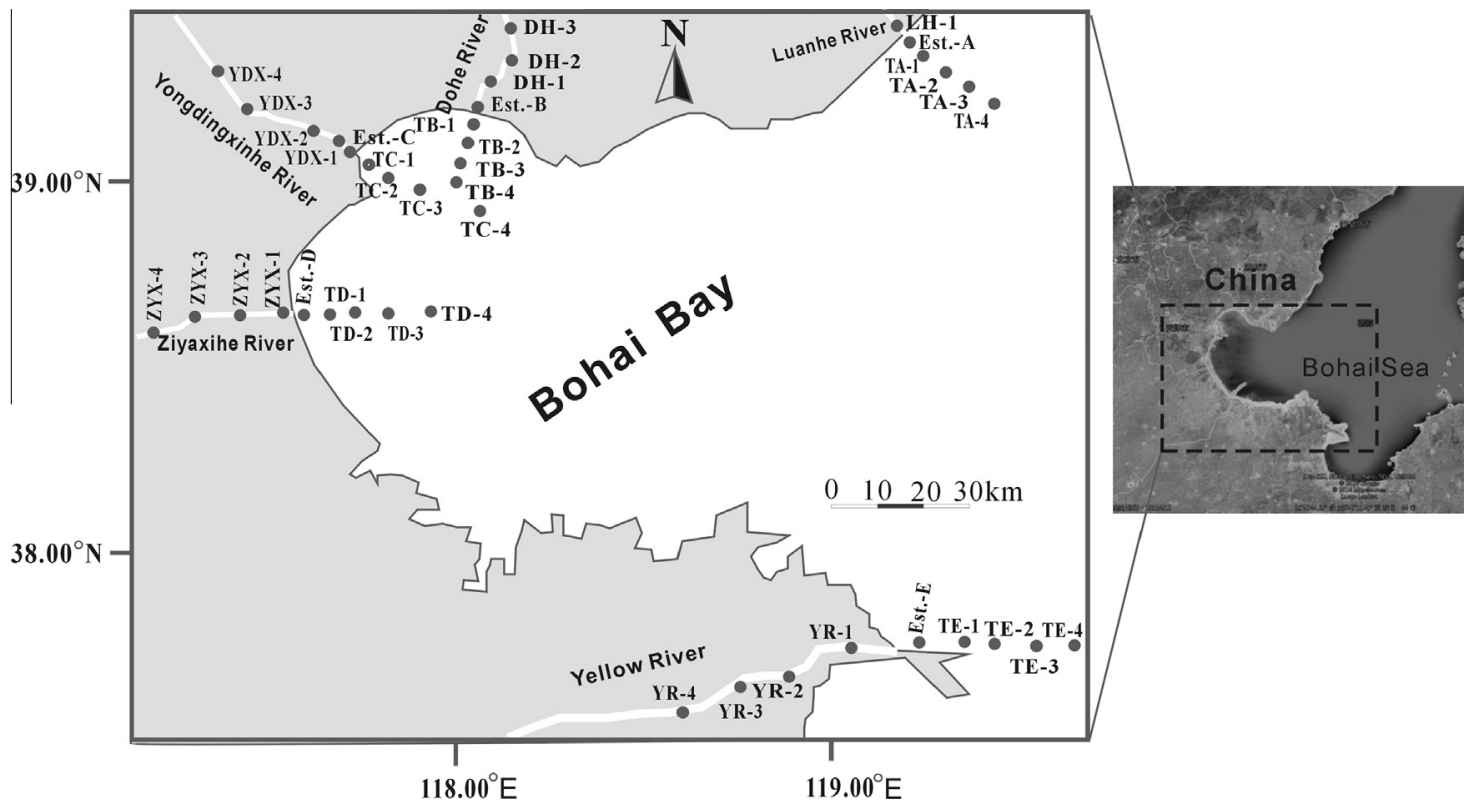

Fig. 1. Location of sampling sites in coastal Bohai Bay. 


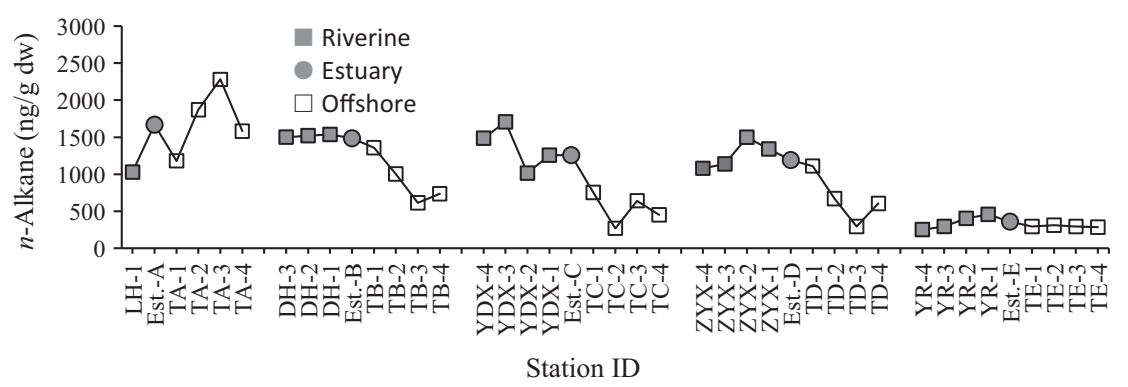

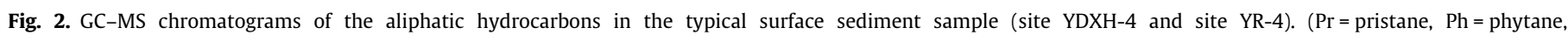
$\mathrm{UCM}=$ unresolved complex mixture.)

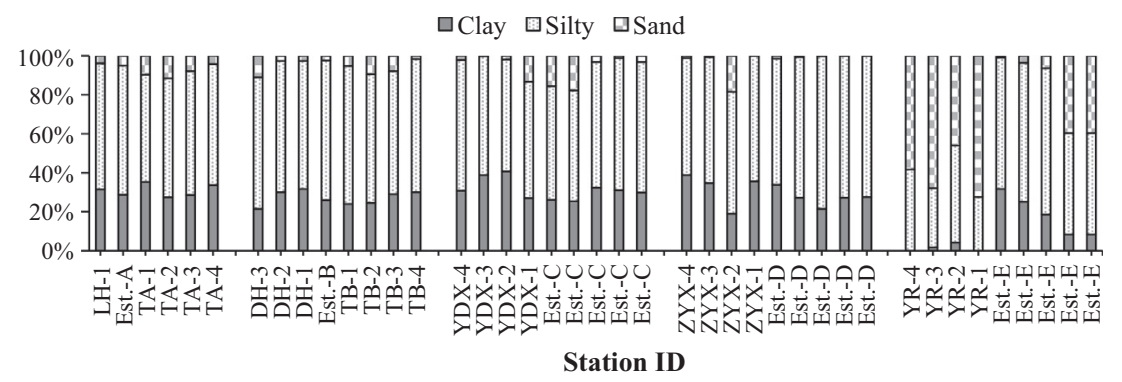

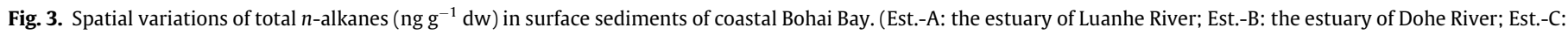
the estuary of Yongdingxinhe River; Est.-D: the estuary of Ziyaxinhe River; Est.-E: the estuary of Yellow River.)

predominance. The second mode (Type $\mathrm{B}$ ) for $n$-alkane ranging from $n-C_{12}$ to $n-C_{34}$, with a maximum at $C_{15}-C_{19}$ and a minor odd/even predominance, was probably caused by both a microbial hydrocarbon contribution and a slight higher plant wax contribution. Except Yellow River and its coastal marine environment, most other samples are all belong to Type A.

The Low Molecular Weight to High Molecular Weight ratio (LMW/HMW), and the Carbon Preference Index (CPI), have frequently been used as source indicators of $n$-alkanes in marine sediments (Prahl et al., 1994; Doskey, 2001; Hu et al., 2009). The LMW/HMW ratios of the samples are all $<1$ for most samples (Fig. 5). We expect that the presence of heavier oil or more degraded crude oil, along with the preferential degradation of light hydrocarbons, would give the observed low ratios of LMW/HMW (<1) as suggested by Commendatore et al. (2000). Contamination from natural hydrocarbon seepage as observed in many coastal environments could also influence the values of LMW/HMW and CPI of $n$-alkanes in sediments depending on the degradation stage of injected oil. On the whole, aliphatic hydrocarbons in 24 out of 40 sediment samples analyzed in the present study were characterized with an obvious odd-even carbon preference, with $\mathrm{CPI}_{24-34}$

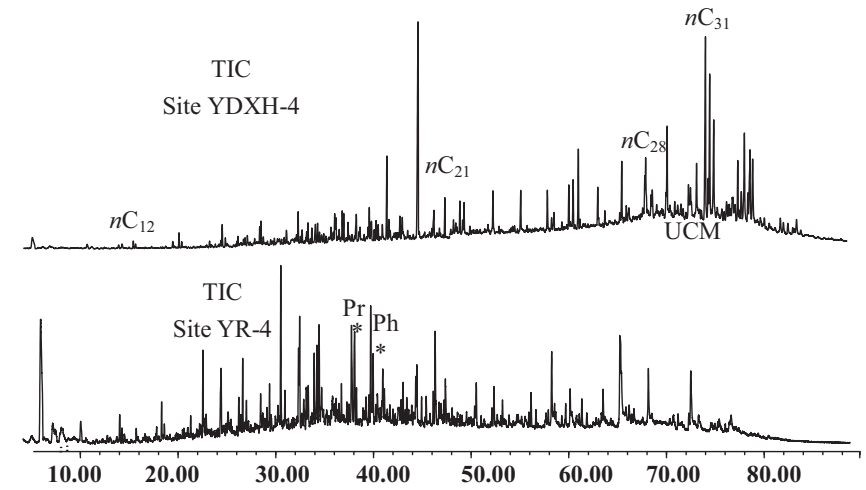

Fig. 4. Diagram showing the sediment classification and deposition patterns. greater than 1 (1.07-2.97) but lower than 3. On the other hand, $\mathrm{CPI}_{24-34}$ in the remaining samples (mainly in Yellow River) contained no obvious odd-even carbon number preference with $\mathrm{CPI}_{24-34}$ around 1, suggested an increasing input of anthropogenic hydrocarbons as well as the mixture of marine bacterial inputs (Harji et al., 2008; Pearson and Eglinton, 2000). $\mathrm{CPI}_{24-34}$ values in surface sediments from riverine sampling sites are apparently lower than that from the marine region (Fig. 6). It reflected that the input of organic matter from anthropogenic activities has a more significant influence on its spatial distribution than from natural processes.

The terrigenous/aquatic ratio (TAR) can evaluate the importance of terrigenous inputs versus aquatic inputs (Mille et al., 2007). The ratio is very high for all stations and confirms the significance of terrestrial inputs in coastal zone area of Bohai Bay (Fig. 7). High TAR values could also be caused by the preferential preservation of terrestrial hydrocarbons over planktonic ones in marine environment. There is a net seaward decrease in TAR in marine sediments. A straightforward explanation for this trend is a progressive seaward decrease in the proportions of terrigenous organic matter relative to marine autogenous organic matter. This explanation is also consistent with the seaward decrease in CPI. However, such a distribution pattern is not very distinct in the marine region of coastal Bohai Bay in this study, which may be due to that the hydrodynamic condition and flat sea-floor of this area make organic matter from different sources well mixed.

The occurrence of unresolved complex mixture (UCM) may be reflective of petroleum contamination and/or chronically degraded complex mixture of hydrocarbons (Gough and Rowland, 1990; Frysinger et al., 2003; Tolosa et al., 2004; Mille et al., 2007). The low values for $\mathrm{UCM} / \Sigma n$-alkane $(<10)$ ratios of this study indicate a pollution diluted by natural input (Silva et al., 2012). In this study, UCM $/ \Sigma n$-alkane ratio values ranged from 1.05 to 3.42 , showing an important biodegradation of petroleum related input. Other indicators of petroleum contamination are isoprenoids, such as pristane and phytane (Volkman et al., 1992). Except for sites YR-2, YR-1 and Estuary-E (Fig. 8), other samples were characterized 


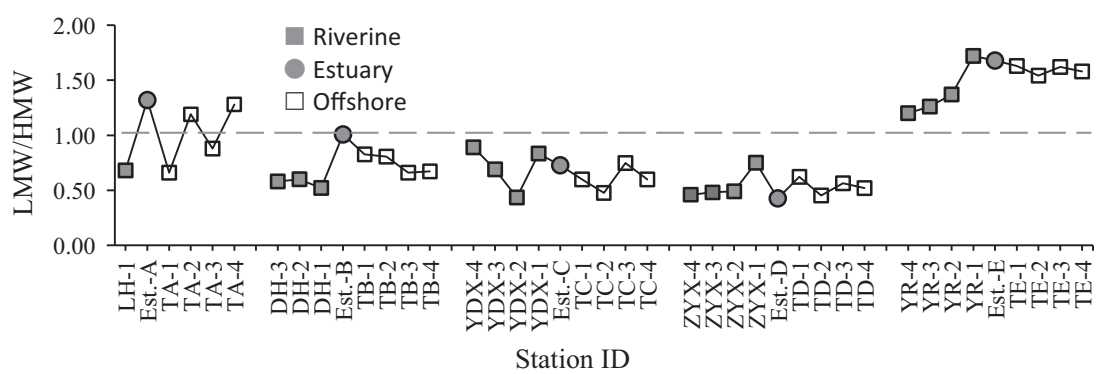

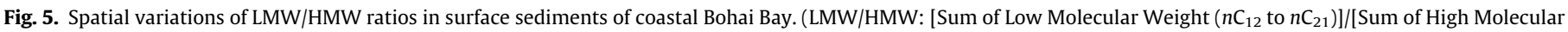
Weight $\left(n \mathrm{C}_{22}\right.$ to $\left.\left.n \mathrm{C}_{34}\right)\right]$-alkanes ratio.)

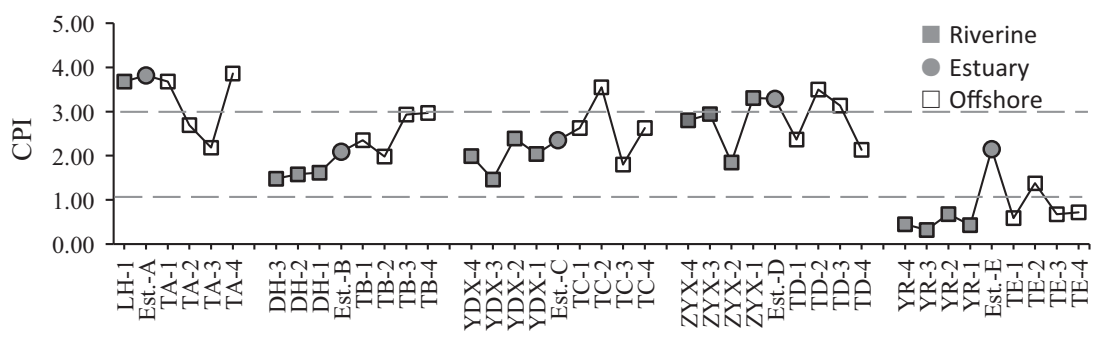

Station ID

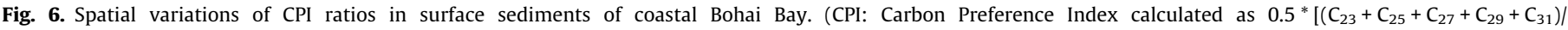
$\left.\left.\left(C_{24}+C_{26}+C_{28}+C_{30}+C_{32}\right)+\left(C_{23}+C_{25}+C_{27}+C_{29}+C_{31}\right) /\left(C_{22}+C_{24}+C_{26}+C_{28}+C_{30}\right)\right].\right)$

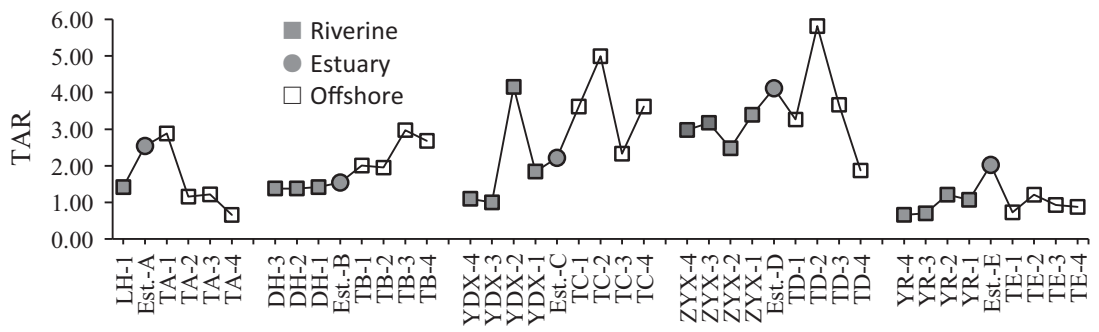

Station ID

Fig. 7. Spatial variations of TAR ratios in surface sediments of coastal Bohai Bay. (TAR: terrigenous/aquatic ratio calculated as $\left(n C_{27}+n C_{29}+n C_{31}\right) /\left(n C_{15}+n C_{17}+n C_{19}\right)$.)

with low $\mathrm{Pr} / \mathrm{Ph}$ values $(0.77 \pm 0.16)$, suggesting predominant petrogenic sources rather than biogenic (zooplanktons and/or marine animals). For recent sediments, the ratios $\operatorname{Pr} / n-\mathrm{C}_{17}$ and $\mathrm{Ph} / n-\mathrm{C}_{18}$ lower than 1 indicate a relatively recent oil input, while values higher than 1 of these indices coupled with high concentrations of hydrocarbons suggest the presence of degraded oil products (Mille et al., 2007; Commendatore et al., 2012). For most stations, low ratio values of $\operatorname{Pr} / n-C_{17}$ and $\mathrm{Ph} / n-\mathrm{C}_{18}$ were found which confirms a recent pollution of oil inputs (Fig. 8).
The presence of oil is also confirmed by the identification of the hopane and sterane series. The hopanes distribution is characterized by the predominance of $C_{30} 17 \alpha(\mathrm{H}), 21 \beta(\mathrm{H})$-hopane with a smooth decrease in the abundance of $\mathrm{C}_{31-35}$ homohopanes in these series. Gammacerane, a nonhopanoid $\mathrm{C}_{30}$ triterpane, was also present in the samples (Fig. 9). This compound is a biomarker commonly found in most Chinese crude oil geologically derived from lacustrine sources (Philp and Fan, 1987). Similar hopane distributions were reported for the petroleum samples from the Shengli

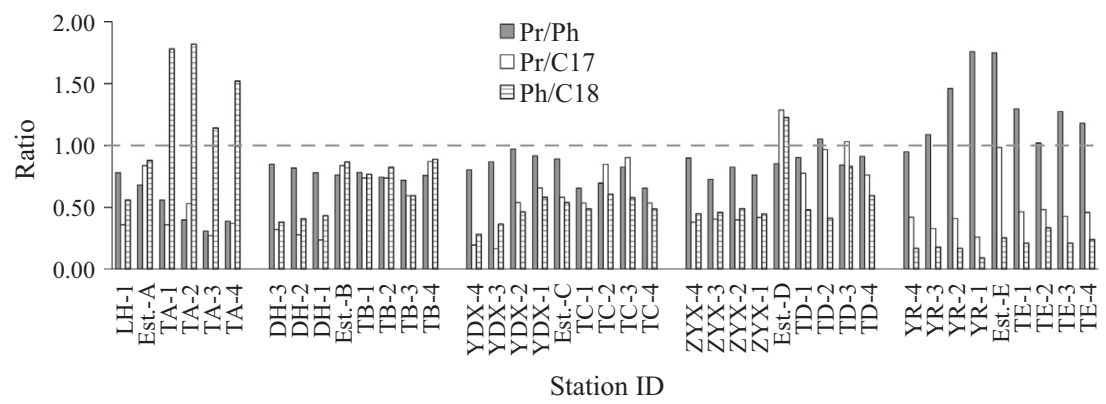

Fig. 8. Spatial variations of $\operatorname{Pr} / \mathrm{Ph}, \operatorname{Pr} / n-C_{17}$ and $\mathrm{Ph} / n-\mathrm{C}_{18}$ ratios in surface sediments of coastal Bohai Bay. 


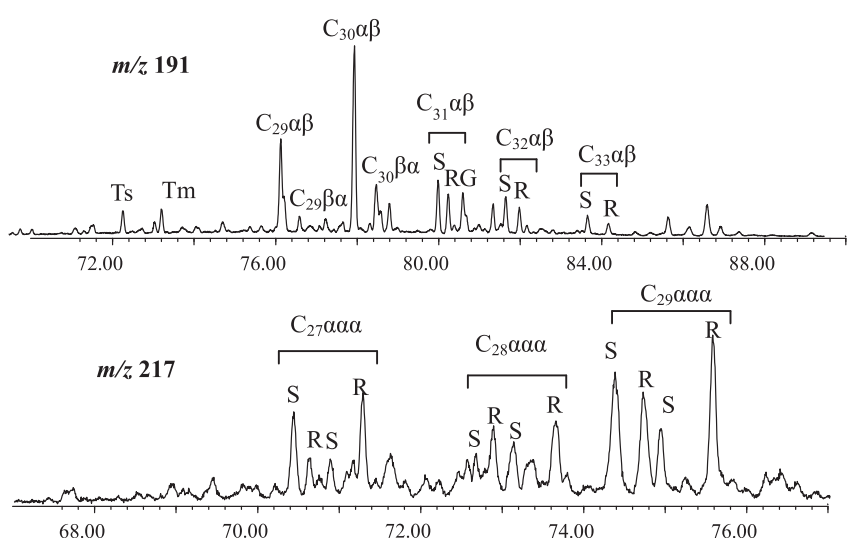

Fig. 9. Mass fragmentogram of $m / z=191$ (hopanes) and $m / z 217$ (steranes) from sediment in site YDX-4. (For hopane, $\alpha, \beta=17 \alpha(\mathrm{H}), 21 \beta(\mathrm{H})$-hopanes; $\beta, \alpha=17 \beta(\mathrm{H})$, $21 \alpha(\mathrm{H})$-hopanes; $\mathrm{R}$ and $\mathrm{S}=\mathrm{C}-22 \mathrm{R}$ and $\mathrm{S}$ configuration; $\mathrm{G}=$ Gammacerane; Ts $=18 \alpha(\mathrm{H})-22,29$, 30-trisnorhopane; $\mathrm{Tm}=17 \alpha(\mathrm{H})-22,29$, 30-trisnorhopane. For steranes, $\alpha \alpha \alpha=5 \alpha(\mathrm{H}), 14 \alpha(\mathrm{H}), 17 \alpha(\mathrm{H})$-steranes; $\alpha \beta \beta=5 \alpha(\mathrm{H}), 14 \beta(\mathrm{H}), 17 \beta(\mathrm{H})$ steranes; $\mathrm{R}$ and $\mathrm{S}=\mathrm{C}-20 \mathrm{R}$ and $\mathrm{S}$ configuration.)

Oilfield (Pang et al., 2003) and the surface sediments in the Yellow River Estuary (Bigot et al., 1989; Wang et al., 2011). The steranes were detected in all samples analyzed and comprised mainly the $5 \alpha, 14 \beta, 17 \beta$ and minor $5 \alpha, 14 \alpha, 17 \alpha$ configurations, both occurring as $20 \mathrm{~S}$ and $20 \mathrm{R}$ epimers (Fig. 9). The relative abundances of three regular sterane series are in an order of $C_{29}>C_{27}>C_{28}$, suggesting the oil contaminate the sediments derived from mixed terrigenous and algal-bacterial organic matter with higher plant as dominanties formed under a weakly reducing. The values of the ratio $22 \mathrm{~S} /$ $22 \mathrm{~S}+22 \mathrm{R}$ epimers of $\alpha \beta \mathrm{C}_{31}$ homohopanes vary in a narrow range $0.55-0.60$, close to the value of 0.6 for equilibrium of oil full maturity (Peters et al., 2005), suggesting petroleum-related hydrocarbon contamination in sediments (Fig. 10a). Maturity indicators based on steranes such as $\mathrm{C}_{29} \alpha \alpha \alpha \mathrm{S} /(\mathrm{S}+\mathrm{R})$ ratio ( 0.5 at equilibrium; Peters et al., 2005) also show only minor variations among the analyzed samples (0.41-0.57) (Fig. 10b) and have the high maturity level. Therefore the occurrence of mature hopanes and steranes in Bohai Bay sediments clearly confirms the input of a fossil fuel contamination.

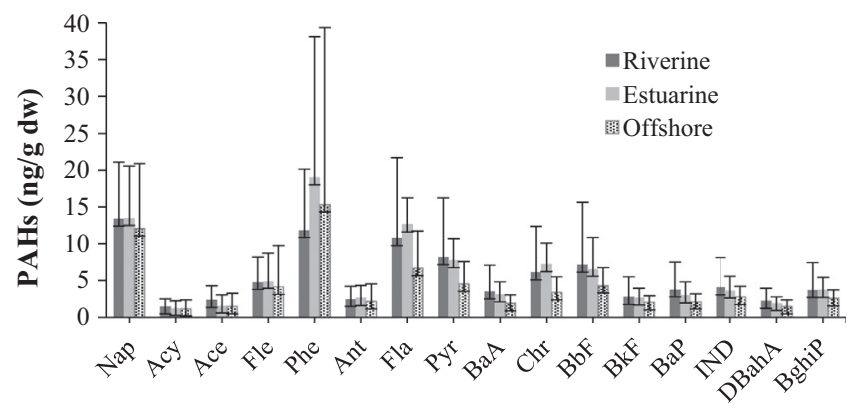

Fig. 11. Spatial variations of $16 \mathrm{PAHs}\left(\mathrm{ng} \mathrm{g}^{-1} \mathrm{dw}\right.$ ) in surface sediments of coastal Bohai Bay.

Bohai has many offshore oilfields. In particular, the Chengdao offshore oilfield, a part of the land-based Shengli Oilfield (the second largest one in China) is in the north of the Yellow River Estuary (YRE). Thus, detecting petroleum-based contaminants in this area should be no surprise. In the coastal areas of the Bohai Bay near Tianjin Harbor, UCM concentrations were also high, suggesting the fugitive petroleum contamination from shipping activities and sewage discharge from the Haihe River.

As a large group of persistent organic pollutants, PAHs can undergo long-range transport and exist for a long time in the environment. Due to their carcinogenicity, mutagenicity, and toxicity, 16 US EPA priority PAHs (16 PAHs) are included in the list of priority pollutants of US EPA. The total concentrations of $\Sigma 16$ PAHs in samples ranged from 24.62 to $280.60 \mathrm{ng} / \mathrm{g}$ dry weight with a mean concentration of $79.27 \pm 52.40 \mathrm{ng} / \mathrm{g}$. Compared with the other area in the world (Tolosa et al., 1996; Yuan et al., 2014), the PAH contamination was lower than those reported from Pearl River Delta (China; 217-2680 ng g $^{-1}$ ), Yangtze River Estuary (China; 90.14$502.12 \mathrm{ng} \mathrm{g}^{-1}$ ), South Carolina marsh (USA; 69-37,000 $\mathrm{ng} \mathrm{g}^{-1}$ ) and Mediterranean coast (Egypt; 3.5-14,100 $\mathrm{ng} \mathrm{g}^{-1}$ ), but higher than the Chongming wetlands (China; 38.7-136.2 $\mathrm{ng} \mathrm{g}^{-1}$ ). The highest concentrations of $\Sigma$ PAHs were found in sites from YDX4, YDX-3, YDX-2, YDX-1, Est.-E, TE-1, TE-2, TE-3, TE-4, in the Yongdingxinhe River and the offshore area near Yellow River. These sites were also characterized with high concentration of
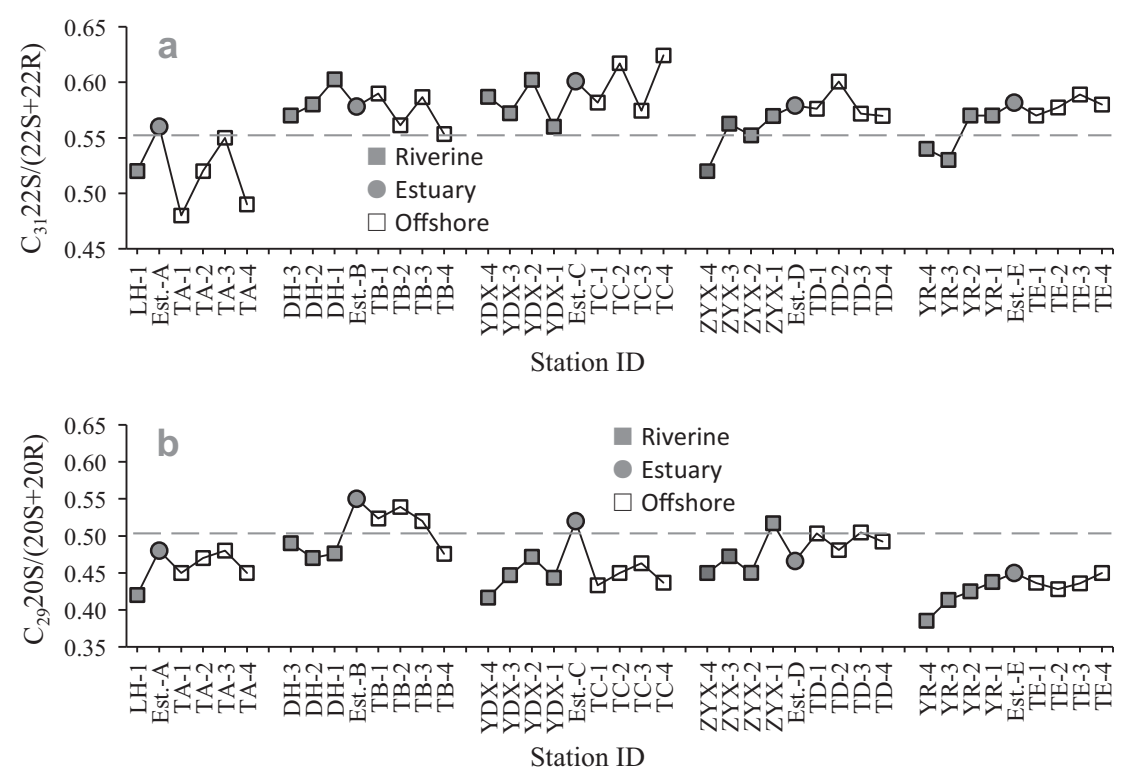

Fig. 10. Spatial variations of $C_{31} 22 S /(22 S+22 R)$ and $C_{29} 20 S /(20 S+20 R)$ ratios in surface sediments of coastal Bohai Bay. 

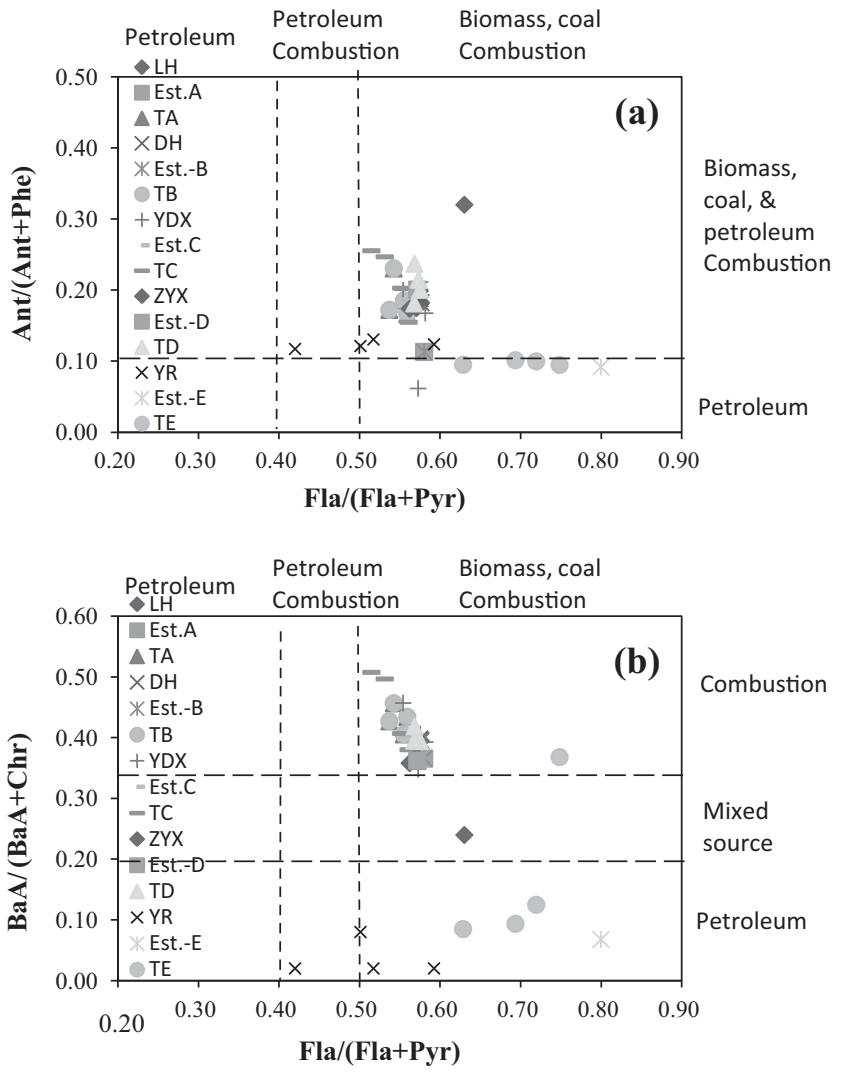

Fig. 12. Diagnostic PAHs ratios of (a) Ant/(Ant/Ant + Phe) versus Fla/(Fla + Pyr) and (b) $\mathrm{BaA}(\mathrm{BaA}+$ Chry) versus Fla/(Fla + Pyr).

the low rings PAHs. The industrial wastewater from Yongdingxinhe River and oil spill from Shengli Oilfield may contribute to this. The spatial distributions of PAHs in surficial sediments from the coastal Bohai are broadly similar with their average values being lower in offshore sediments than in riverine ones and estuarine (Fig. 11).

PAHs are introduced into environmental compartments both from natural (organic matter diagenesis, plant synthesis, forest and prairie fires, volcanoes, etc.) and anthropogenic processes (fossil fuel burning, incomplete combustion of organic matter, petroleum, incineration, etc.). Diagnostic ratios of PAHs, such as Ant/ (Ant + Phy $), \mathrm{BaA} /(\mathrm{BaA}+\mathrm{Chry})$ and Flu/(Flu + Pyr) have been developed to identify the possible sources of PAHs (Yunker et al.,
2002; Yang et al., 2009). In summary, it can be seen that the samples for YR, Est.-E, TE and DH exhibited more evidence of petroleum derived pollution (Fig. 12), while other samples may be derived primarily from biomass and coal combustion. Except pyrolytic input as a major source, petrogenic may be also a source for PAHs may be due to Shengli Oilfield and other oilfield drilling platforms in Bohai Bay.

Sediment quality guidelines (SQGs) are an important tool for the assessment of contamination in marine and estuarine sediments (Long et al., 1995; Quiroz et al., 2010). Two sets of SQGs, including (a) the ERL/ERM and (b) the TEL/PEL values, were applied in this study to assess the ecological toxicity of individual PAHs concentrations in sediments (Fig. 11; Table 1). In the three ranges of chemical concentrations, adverse biological effects were expected rarely (<ERL/TEL), occasionally ( $\geqslant$ ERL/TEL and $<$ ERM/ PEL), and frequently ( $\geqslant$ ERM/PEL) (Long et al., 1995; Qiao et al., 2006). It showed that concentrations of all PAHs were below their respective ERL and PEL values in all stations by the comparison of pollutants levels with SQGs. It may be concluded that PAHs will not cause immediately adverse biological effects in sediments from Bohai Bay and its adjacent river, China.

The anthropogenic activities have a significant influence on the geochemistry of organic matter in riverine sediments besides natural processes; the spatial distributions of LMW/HMW, CPI and TAR in marine sediments are mainly controlled by the mixing inputs of terrigenous and marine components. The ubiquitous presence of UCM, composition patterns of hopanes and steranes, and $\mathrm{Pr} / n-\mathrm{C}_{17}, \mathrm{Ph} / n-\mathrm{C}_{18}$ ratios indicated that the petroleum contamination in Bohai Bay was mainly from the offshore oilfields and sewage discharges from the surrounding rivers. PAHs isomeric ratios indicated that the PAHs in sediments were mostly of pyrogenic origin; while various sites in Yellow River Estuary were derived mainly from the petrogenic sources. PAHs will not cause immediately adverse biological effects in sediments from Bohai Bay and its adjacent river, China.

\section{Acknowledgements}

This study was co-supported by the " $1-3-5$ " Research Program of Yantai Institute of Coastal Zone Research, Chinese Academy of Sciences (Nos. Y455011031 and Y254021031), Key Research Program of the Chinese Academy of Sciences (No. KZZD-EW-14), National Natural Science Foundation of China (No. 41376138) and Key Projects in the Yantai Science \& Technology Pillar Program (No. 2011060).

Table 1

Toxicity guidelines of PAHs compounds for sediment matrices $\left(\mathrm{ng} \mathrm{g}^{-1}\right)$ and maximum concentrations in the surface sediments.

\begin{tabular}{|c|c|c|c|c|c|c|c|c|c|c|}
\hline \multirow[t]{3}{*}{ PAHs } & \multirow{2}{*}{\multicolumn{4}{|c|}{ Guideline }} & \multicolumn{6}{|c|}{ This study } \\
\hline & & & & & \multicolumn{3}{|l|}{ Max } & \multicolumn{3}{|l|}{ Ave } \\
\hline & ERL & ERM & TEL & PEL & Riverine & Estuary & Offshore & Riverine & Estuary & Offshore \\
\hline Nap & 160 & 2100 & 34.6 & 391 & 27.79 & 25.38 & 34.35 & 13.38 & 13.44 & 12.03 \\
\hline Ace & 16 & 500 & 6.71 & 88.9 & 3.38 & 2.97 & 4.03 & 1.49 & 1.23 & 1.17 \\
\hline Acy & 44 & 640 & 5.87 & 128 & 6.90 & 4.17 & 5.95 & 2.37 & 1.57 & 1.46 \\
\hline Flu & 19 & 540 & 21.2 & 144 & 10.27 & 11.60 & 19.24 & 4.77 & 4.92 & 4.15 \\
\hline Phe & 240 & 1500 & 86.7 & 544 & 35.25 & 53.08 & 90.82 & 11.83 & 19.00 & 15.30 \\
\hline Ant & 85.3 & 1100 & 46.9 & 245 & 8.34 & 5.37 & 9.53 & 2.47 & 2.65 & 2.15 \\
\hline Fla & 600 & 5100 & 113 & 1494 & 43.62 & 17.03 & 23.73 & 10.75 & 12.59 & 6.66 \\
\hline Pyr & 665 & 2600 & 153 & 1398 & 32.54 & 11.32 & 14.02 & 8.16 & 7.77 & 4.52 \\
\hline $\mathrm{BaA}$ & 261 & 1600 & 74.8 & 693 & 13.29 & 5.00 & 4.35 & 3.51 & 3.12 & 1.87 \\
\hline Chr & 384 & 2800 & 108 & 846 & 24.89 & 11.31 & 9.87 & 6.12 & 7.21 & 3.37 \\
\hline Bap & 430 & 1600 & 88.8 & 763 & 15.11 & 5.04 & 4.28 & 3.77 & 2.97 & 2.13 \\
\hline DahA & 63.4 & 260 & 6.22 & 135 & 4.81 & 2.92 & 2.43 & 2.25 & 1.91 & 1.47 \\
\hline
\end{tabular}

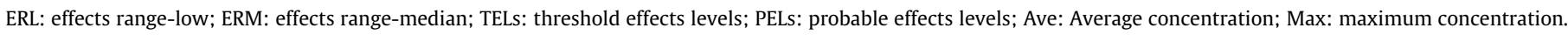




\section{References}

Bigot, M., Saliot, A., Cui, X., Li, J., 1989. Organic geochemistry of surface sediments from the Huanghe estuary and adjacent Bohai Sea (China). Chem. Geol. 75, 339350.

Bouloubassi, I., Fillaux, J., Saliot, A., 2001. Hydrocarbons in surface sediments from the Changjiang (Yangtze River) estuary, East China Sea. Mar. Pollut. Bull. 42, 1335-1346.

Commendatore, M.G., Esteves, J.L., Colombo, J.C., 2000. Hydrocarbons in coastal sediments of Patagonia, Argentina: levels and probable sources. Mar. Pollut. Bull. 40, 989-998.

Commendatore, M.G., Nievas, M.L., Amin, O., Esteves, J.L., 2012. Sources and distribution of aliphatic and polyaromatic hydrocarbons in coastal sediments from the Ushuaia Bay (Tierra del Fuego, Patagonia, Argentina). Mar. Environ. Res. 74, 20-31.

Doskey, P.V., 2001. Spatial variations and chronologies of aliphatic hydrocarbons in Lake Michigan sediments. Environ. Sci. Technol. 35, 247-254.

Frysinger, G.S., Gaines, R.B., Xu, L., Reddy, C.M., 2003. Resolving the unresolved complex mixture in petroleum contaminated sediments. Environ. Sci. Technol. 37, 1653-1662.

Gao, X.L., Yang, Y.W., Wang, C.Y., 2012. Geochemistry of organic carbon and nitrogen in surface sediments of coastal Bohai Bay inferred from their ratios and stable isotopic signatures. Mar. Pollut. Bull. 64, 1148-1155.

Gough, M.A., Rowland, R.J., 1990. Characterization of unresolved complex mixtures of hydrocarbons in petroleum. Nature 344, 648-650.

Harji, R.R., Yvenat, A., Bhosle, N.B., 2008. Sources of hydrocarbons in sediments of the Mandovi estuary and the Marmugoa harbor, west coast of India. Environ. Int. 34, 959-965.

Hu, J.Y., Wan, Y., Shao, B., Jin, X.H., An, W., Jin, F., Yang, M., Wang, X.J., Sugisaki, M., 2005. Occurrence of trace organic contaminants in Bohai Bay and its adjacent Nanpainu River, North China. Mar. Chem. 95, 1-13.

Hu, L.M., Guo, Z.G., Feng, J.L., Yang, Z.S., Fang, M., 2009. Distributions and sources of bulk organic matter and aliphatic hydrocarbons in surface sediments of the Bohai Sea, China. Mar. Chem. 113, 197-211.

Kanzari, F., Syakti, A.D., Asia, L., Malleret, L., Piram, A., Mille, G., Doumenq, P., 2014. Distributions and sources of persistent organic pollutants (aliphatic hydrocarbons, PAHs, PCBs and pesticides) in surface sediments of an industrialized urban river, France. Sci. Total Environ. 478, 141-151.

Liu, A.X., Lang, Y.H., Xue, L.D., Liu, J., 2009. Ecological risk analysis of polycyclic aromatic hydrocarbons (PAHs) in surface sediments from Laizhou Bay. Environ. Monit. Assess. 159, 429-436.

Liu, J.Y., Wang, J.Z., Guan, Y.F., Zeng, E.Y., 2012. Use of aliphatic hydrocarbons to infer terrestrial organic matter in coastal marine sediments off China. Mar. Pollut. Bull. 64, 1940-1946.

Long, E.R., MacDonald, D.D., Smith, S.L., Calder, F.D., 1995. Incidence of adverse biological effects within ranges of chemical concentrations in marine and estuarine sediments. Environ. Manage. 19, 81-97.

Ma, M., Feng, Z., Guan, C., Ma, Y., Xu, H., Li, H., 2001. DDT, PAH and PCB in sediments from the intertidal zone of the Bohai Sea and the Yellow Sea. Mar. Pollut. Bull. 42, 132-136.

Medeiros, P.M., Caruso Bíego, M., 2004. Investigation of natural and anthropogenic hydrocarbon inputs in sediments using geochemical markers. I. Santos, SP Brazil. Mar. Pollut. Bull. 49, 761-769.

Mille, G., Asia, L., Guiliano, M., Malleret, L., Doumenq, P., 2007. Hydrocarbons in coastal sediments from the Mediterranean sea (Gulf of Fos area, France). Mar. Pollut. Bull. 54, 566-575.

Pang, X., Li, M., Li, S., Jin, Z., 2003. Geochemistry of petroleum systems in the Niuzhuang South Slope of Bohai Bay Basin. Part 2: evidence for significant contribution of mature source rocks to "immature oils" in the Bamianhe field. Org. Geochem. 34, 931-950.
Pearson, A., Eglinton, T.I., 2000. The origin of $n$-alkanes in Santa Monica Basin surface sediment: a model based on compound-specific $\delta^{14} \mathrm{C}$ and $\delta^{13} \mathrm{C}$ data. Org. Geochem. 31, 1103-1116.

Peters, K.E., Walters, C.C., Moldowan, J.M., 2005. The Biomarker Guide, Biomarkers and Isotopes in Petroleum Exploration and Earth History,... vol. 2, second ed. Cambridge University Press, UK.

Philp, R.P., Fan, Z., 1987. Geochemical investigation of oils and source rocks from Qianjing Depression of Jianhan Basin, a terrigenous saline basin, China. Org. Geochem. 11, 549-562.

Prahl, F.G., Ertel, J.R., Goni, M.A., Sparrow, M.A., Eversmeyer, B., 1994. Terrestrial organic carbon contributions to sediments on the Washington margin. Geochim. Cosmochim. Acta 58, 3035-3048.

Qiao, M., Wang, C., Huang, S., Wang, D., Wang, Z., 2006. Composition, sources, and potential toxicological significance of PAHs in the surface sediments of the Meiliang Bay, Taihu Lake, China. Environ. Int. 32, 28-33.

Quiroz, R., Grimalt, J.O., Fernandez, P., 2010. Toxicity assessment of polycyclic aromatic hydrocarbons in sediments from European high mountain lakes. Ecotoxicol. Environ. Saf. 73, 559-564.

Silva, T.R., Lopes, S.R.P., Spörl, G., Knoppers, B.A., Azevedo, D.A., 2012. Source characterization using molecular distribution and stable carbon isotopic composition of $n$-alkanes in sediment cores from the tropical MundaúManguaba estuarine-lagoon system, Brazil. Org. Geochem. 53, 25-33.

Sultan, S.A., Sameer, J.G., 1997. Hydrocarbon distributions in sediments of the open areas of the Arabian Gulf following the 1991 Gulf War oil spill. Mar. Pollut. Bull. 34, 941-948.

Thornton, S.F., McManus, J., 1994. Application of organic carbon and nitrogen stable isotope and $C / N$ ratios as source indicators of organic matter provenance in estuarine systems: evidence from the Tay Estuary, Scotland. Estuar. Coast. Shelf Sci. 38, 219-233.

Tolosa, I., Bayona, J.M., Albaiés, J., 1996. Aliphatic and polycyclic aromatic hydrocarbons and sulfur/oxygen derivatives in northwestern Mediterranean sediments: spatial and temporal variability, fluxes, and budgets. Environ. Sci. Technol. 30, 2495-2503.

Tolosa, I., Mora, S., Sheikholeslami, M.R., Villeneuve, J.P., Bartocci, J., Cattini, C., 2004 Aliphatic and aromatic hydrocarbons in coastal Caspian Sea sediments. Mar. Pollut. Bull. 48, 44-60.

Volkman, J.K., Holdsworth, D.G., Neill, G.P., Bavor Jr., H.J., 1992. Identification of natural, anthropogenic and petroleum hydrocarbons in aquatic sediments. Sci. Total Environ. 112, 203-219.

Wang, X.C., Sun, S., Ma, H.Q., Liu, Y., 2006. Sources and distribution of aliphatic and polyaromatic hydrocarbons in sediments of Jiaozhou Bay, Qingdao, China. Mar. Pollut. Bull. 52, 129-138.

Wang, C., Wang, W., He, S., Du, J., Sun, Z., 2011. Sources and distribution of aliphatic and polycyclic aromatic hydrocarbons in Yellow River Delta Nature Reserve, China. Appl. Geochem. 26, 1330-1336.

Yang, Z.F., Wang, L.L., Niu, J.F., Wang, J.Y., Shen, Z.Y., 2009. Pollution assessment and source identifications of polycyclic aromatic hydrocarbons in sediments of the Yellow River Delta, a newly born wetland in China. Environ. Monit. Assess. 158, 561-571.

Yuan, H.M., Li, T.G., Ding, X.G., Zhao, G.M., Ye, S.Y., 2014. Distribution, sources and potential toxicological significance of polycyclic aromatic hydrocarbons (PAHs) in surface soils of the Yellow River Delta, China. Mar. Pollut. Bull. 83, 258-264.

Yunker, M.B., Macdonald, R.W., Vingarzan, R., Mitchell, R.H., Goyette, D., Sylvestre S., 2002. PAHs in the Fraser River basin: a critical appraisal of PAH ratios as indicators of PAH source and composition. Org. Geochem. 33, 489-515.

Zanardi, E., Bícego, M.C., de Miranda, L.B., Weber, R.R., 1999. Distribution and origin of hydrocarbons in water and Sediment in São Sebastião, SP, Brazil. Mar. Pollut. Bull. 38, 261-267.

Zhou, H., Zhang, Z.N., Liu, X.S., Yu, Z.S., 2007. Changes in the shelf macrobenthic community over large temporal and spatial scales in the Bohai Sea, China. J. Mar. Syst. 67, 312-321. 